\title{
SCHOOLS OF ESTONIAN GRAPHIC ART IN JOURNALISM IN THE 1930S
}

\author{
Merle Talvik
}

\begin{abstract}
The basis for the development and spread of graphic design in the 1920 s and 30s in Estonia was the rapid progress of the country's economy and commerce. The rise in the number of publications led to a greater need for designers. The need for local staff arose in all fields of applied graphics. In the 1930 s, graphic artists were trained at two professional art schools - the State Applied Art School (Riigi Kunsttööstuskool) in Tallinn and the Higher Art School (Kõrgem Kunstikool) Pallas in Tartu. The present article focuses on the analyses of the creative work of the graphic artists of both schools, trying to mark the differences and similarities.

The State Applied Art School was established in 1914. In 1920, Günther Reindorff started working as a drawing teacher. His teaching methods and the distinguished style of his creative work became an inspiration for an entire generation of Estonian graphic designers. The three well-known students and followers of G. Reindorff were Johann Naha, Paul Luhtein and Hugo Lepik. The teachers and students of the State Applied Art School shaped greatly the appearance of magazines printed in Tallinn. Of modern art movements, art deco found most followers. National ornament became a source for creative work. Distinct composition and beautifully designed legible script are also the features that resulted from the systematic education of the State School of Applied Art.

The curriculum of the Higher Art School Pallas, established in 1919, was based on western European art experience. Therefore the visual language of the artists from the Tartu school is often picturesque; influences of expressionism and constructivism are visible. Individualities emerge very clearly. National propaganda is latent in comparison with the Tallinn school, but the script is often unprofessional. The most important representatives of the Tartu school were Nikolai Triik, Ado Vabbe ja Hando Mugasto. Very productive graphic designers were also Jaan Vahtra, Peet Aren, Ernst Kollom and Agu Peerna.

In addition to these names, there was quite a number of self-taught graphic designers active in Estonia, such as Heino Lehepuu, Paul-Aleksander Pedersen, Karl Taev, August Vahtel, Karl Vanaveski and Valter Kõrver. They were mostly involved in advertising art.
\end{abstract}

Key words: graphic design journals, applied graphics, Estonian graphic art, State Applied Art School, Higher Art School Pallas 


\section{INTRODUCTION}

The years 1930-1940 saw the first rise in Estonian applied graphic art. This was a period when the keywords in art were order, monumentalism, nationalism, classics and hierarchy (Borsi 1987: 13), which in the context of Estonia were very clearly expressed in architecture (Kalm 1994: 93-136; Kodres 2001: 236-240), and also in applied art and applied graphic art. The young Estonian national culture, with its identity to protect, had taken the direction of internationalism via nationalism. In a few decades, Estonian culture developed extremely fast. In 1968, B. Bernstein introduced the relatively new term "national culture accelerated development" in Estonian art history.

B. Bernstein (1979: 128) claims that in order for the national school to develop into an entirely viable independent organism, it must create and develop a complete structure of artistic life, which, in addition to artistic communication, contains all the principal mechanisms of recreation and self-regulation. The moment at which the structure is ready may be viewed as a frontier beyond which intensive development changes into normal development. In Estonian art all the principal components of this scheme were formed between 1920 and 1930, meaning that a structure of art culture corresponding to the nation was created in the first ten years. Proceeding from this idea, it is important to note that at the time when the structure of Estonian artistic life was becoming consolidated, and the transition from intensive to normal development was taking place, the study systems of two art education institutions, the intermediate Tallinn (from 1924 Riigi) Kunsttööstuskool (State Applied Art School) and Kõrgem Kunstikool Pallas (Higher Art School Pallas) were becoming stabilised. Among artists the importance of those who studied in Estonia increased, while artistic schools with a definite creative expression developed. The creative language of artists from both schools still carries the traces of intensive development. The State Applied Art School mostly influenced the development of our applied and graphic art. Applied graphic art was at the time associated with applied art or industrial art, with, for example, applied graphic artists appearing with their works at the RaKÜ1 (Association of Applied Artists) exhibitions. The Pallas school was the first school of painting and sculpture to be set up and to operate in normal conditions of development. A number of talented graphic artists graduated from this school too, many of whom were engaged in applied graphic art. Regarding the artistic training of applied graphic artists, it must be said that among the older generation there were only a few with specific applied graphic art training, most notably Guido Mamberg ${ }^{2}$ and Edmond Arnold Blumenfeldt ${ }^{3}$. The rapid development of the 
economy and trade encouraged the emergence of a whole rank of self-taught artists and designers in applied graphic art.

A considerable amount of printed applied graphic art was published in journals. Thus an analysis of graphic art in journalism provides quite a good overview of what took place in applied graphic art. The current article focuses on an analysis of the different schools of graphic art in journalism, highlighting their specifics and originality.

\section{THE TALLINN SCHOOL}

The Tallinn (from 1924 Riigi) Kunsttööstuskool (State Applied Art School) was the first educational institution to provide systematic art education in Estonia. Earlier craft schools did not claim to be on the level of professional art and studio schools mostly limited themselves to practical training. A number of applied art schools had been founded in Europe in the second half of the 19th century, in order to train artists for the newly-built factories. Studies in these schools, characteristic of the era, had an eclectic and historicist manner. But the future artists, who studied in these schools, learned technical skills in many fields of applied art, acquiring proficiency in the fields of ornament and form, and becoming professionals in their fields (Kirme 1975: 14).

When the curriculum of the Tallinn Applied Art School was created, the Baron Stieglitz Central School of Technical Drawing, which had opened in St. Petersburg in 1879, served as an example. The founder of the school was the industrialist, banker and patron of the arts Alexander Stieglitz (1814-1884), whose name is also famous in Estonia ${ }^{4}$. The objective of the Stieglitz school was to train draughtsmen and designers for industry in Russia, not creative artists. For the common people the studying conditions in the Stieglitz school were more acceptable than those in other art educational institutions, and about 60 Estonians received their education there, including the artists Jaan Koort, Voldemar Mellik, Konrad Mägi, Nikolai Triik, Roman Nyman, Aleksander Tassa and Günther Reindorff.

In 1912, Voldemar Päts5 (1878-1958), a student of the Stieglitz Applied Art School, opened Graphic Arts courses at the Estonian Society of Art together with his associates. In 1914, the Tallinn Applied Art School was founded on the basis of these courses, and the board of trustees elected Voldemar Päts as the director. Studies at the Tallinn Applied Art School lasted for five years and the graduates were awarded the title of trained draughtsman. At first general subjects and general art subjects such as drawing were taught, but step-bystep several applied arts were added (Kirme 1994). Until recently the Applied 
Arts School was severely criticised. According to M. Levin and E. Sirkel (1989: 5 ) it focused excessively on figurative art. The school has been reproached for putting too much stress on stylisation, but the tuition of historical styles corresponded with the school's speciality. You could not demand that an applied art school provide such skills as were gained from an art academy or private studio. Compared to the level of the Higher Art School Pallas, the Applied Art School had rather weak branches of figurative arts, but a strong teaching staff for graphic art. In 1920 Günther Reindorff (1889-1974) began working at the Applied Art School. At first he was a drawing teacher, and from 1922 he was head of the graphic art studies workshop.

The State Applied Art School had extensive foreign relations with art and applied art schools in Germany. These schools were considered the best and most effective in Europe. Their objectives and principles were generally appropriate for Estonia too (Riigi... 1938-1939: 147-153). Both students and teachers went on trips abroad for professional training; the most successful of G. Reindorff's students were sent to continue their education: Paul Luhtein to the Leipzig Academy of Graphic and Book Art, Gerda Hofmann to the Vienna Academy, Salome Trei to Pallas (Riigi... 1938-1939: 309, 310).

The emergence of the students of the State Applied Art School into artistic life already began while they were still in school. The range of activity of students of graphic art was especially extensive. They participated in illustrating books and designing magazines and were successful in competitions for advertisements. Linda Ormesson, a graduate of the school, together with her sister Johanna, published a house and home journal Kaunis Kodu (Beautiful Home), which was published 1934-1938 and also on its pages reported on the activities of the alumni of the State Applied Art School (Toom 2004: 90). The graduates of the State Applied Art School largely designed the visual appearance of the journals published in Tallinn in the 1930s.

Tallinn as the capital was the centre of political power, and Tallinn journals had a Tallinn face. One important characteristic that differentiates the Tallinn journals from the Tartu ones was nationalism. In the middle of the 1930s the aesthetic principles began to be regulated by the state. The more strongly the government of Konstantin Päts asserted its power, the clearer the aspirations of the political unification of culture were. The early history of the nation and art were treated in an ideal manner, with a romantic pathos. Support for the government's positivity and national entity programme was best served by being grounded in folk art. At the same time, a greater interest in national ornaments was a kind of self-defence against foreign influences and examples coming from outside ${ }^{6}$. Of course, the interest in indigenous and folk art was generally very characteristic of the art deco era. The issue of nationalism became 
the centre of attention in all spheres of life in Estonia in the 1930s. In art the national romantic movement had more or less reached its second stage. The first stage coincided with the Noor-Eesti ${ }^{7}$ (Young Estonia) movement. In the 1920 s, once independence had been achieved, "becoming European" was more topical, whether through classical or modern art (Kodres 2001: 42). But in the 1930s a counter-movement emerged as a certain protest, demanding respect for Estonian indigenous culture and its use in modern art. Nationalism was propagated in journals where Bernhard Linde, Johannes Semper, AdamsonEric, Sten Karling, Rasmus Kangro-Pool and others spoke out on issues of nationalism. Journals on rural life influenced the look of Estonian country homes, thus the look of the entire homeland. The era of the home decoration working campaign was in progress, which meant that people wanted to make simple Estonian homes beautiful, decent and loveable both internally and externally.

An unquestioned authority for the generation of the State Applied Art School, both in designing ornaments and in calligraphy was Günther Reindorff, whose characteristically individual hand developed under the influence of the creative work of the graphic book artists of the Russian group Mir Iskusstva. The latter aspired for finesse, refinement and decorativeness in design, focusing their attention on the decorative side of the book and subjecting the content of the work to it. The fine polish of the drawing side, direct calligraphic stylisation, and attention to the expressiveness and beauty of the drawn font characterise the creative work of Günther Reindorff. In his graphic designs Reindorff is able to create an integral ornament of motifs borrowed from folk $\operatorname{art}^{8}$ and apply them in a new creation, and then unite this font with drawings into a rich artistic ensemble. There is a close connection between the font, the ornament and the drawing and it is predominantly the ornament which is used to make the design a whole. The artist is fond of ornament both in the general composition and in decorating single letters. At the same time his designs of plant ornaments do not leave an impression of a garden, as was often the case in Estonian design during the years after World War II. In stylising the ornament, Reindorff mostly borrows from art deco $^{9}$. His works are characterised by decorativeness, a striving for representativeness, and a stylisation combining angularity with rotundity and fine graphicality.

In calligraphy Reindorff laid the foundation for the correct methodology of teaching font in Estonia. In the second half of the 1920s and at the beginning of the 1930s Reindorff developed a special ornamental font, unique to him, which is characterised by the narrowing of the principal lines of the letters downwards. The font was devised from Roman type and Gothic uncialis. Such a font was used by many of his students and followers. Students from the applied art 
school passed their skills on to their pupils and thus the traditions of calligraphy in Estonia spread and grew deeper. In addition to this, the creative work of the master himself was an important factor that made the art of calligraphy popular. It involved circles outside the art school and its fine elegance has actually remained unsurpassed, for all his numerous epigones. According to Villu Toots (1970: 10), Reindorff may justifiably be considered the father of modern Estonian calligraphy.

In 1928 Günther Reindorff created the title illustration for the journal of the Eesti Lauljate Liit (Estonian Singers' Federation) Muusikaleht (Music Journal), and in 1936-1940 an elegant integral design title in italics with ornament decorations, which has all the principal art deco features (Figure 1). In the issues of the last two years, the design becomes simpler and the ornament disappears.

In the years 1930-1935, the entire design of the Muusikaleht was completed by Reindorff's student Johann Naha (1902-1982), who studied at the State Applied Art School department of graphic art in 1923-1929, completing a sixyear course. In the early creative work of Johann Naha Reindorff's influence is clearly expressed: the design is ornamental and is based on font, and the artist uses many vignettes and decorative initials. Later Naha's style becomes
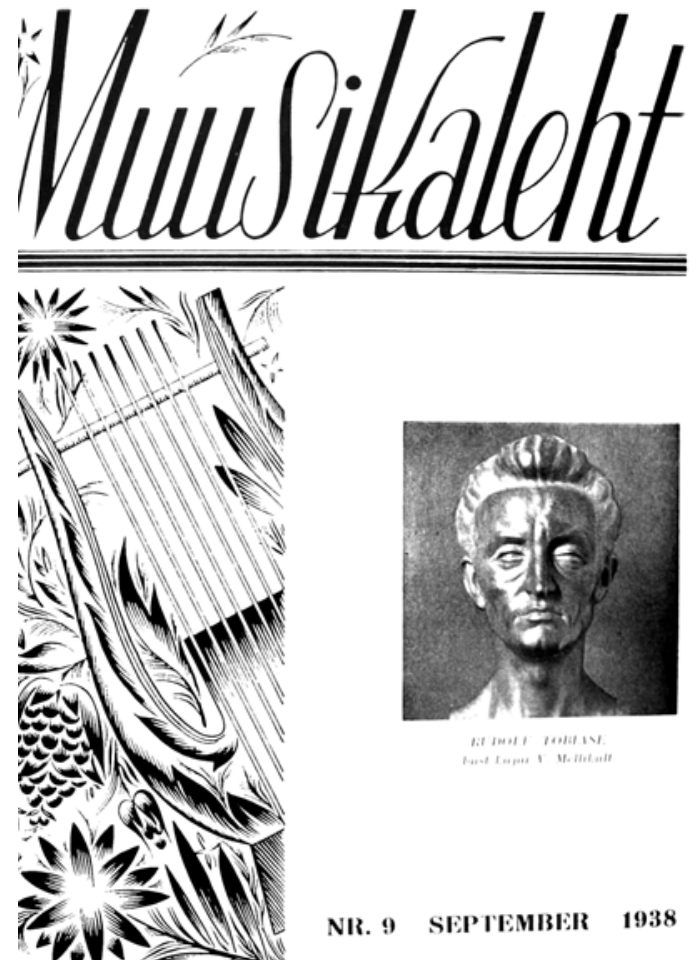
freer. For Muusikaleht he created ornament vignettes in a nationalist style and lino-cuts and font designs in a much freer style. His creative work is characterised by engraving-like decorativeness. Johann Naha also provided designs for several Christian journals and house and home journals. In addition to this, he created large amounts of advertisement graphic art, most of which was published in journals.

Paul Luhtein (born in 1909) was a productive book and applied graphic artist and calligrapher

Figure 1. Günther Reindorff. Magazine cover. Muusikaleht (Music Journal), no 9, 1938. 
who, in his student years and early creative work, was deeply influenced by Reindorff's creative style, but who later discovered his own individual style based on a clearer font and strict architectonics. His creative output was vast and many-sided. He created applied graphic art in all fields, and also graphic art and designs for applied art. He entered the State Applied Art School in 1924, graduating from the school in 1930 as an applied artist. The artist trained in 1931-1932 as a national grant holder at the Leipzig Academy of Graphic and Book Art. The decorative, ornamental manner acquired at the Applied Art School was complemented by the simplicity and typography-likeness of the font, the soberness of the compositional solutions and functionalism, and the aspiration for integrity learned at Leipzig (Loodus 1980: 6). These two controversial methods determined Luhtein's artistic style. In 1932-1940 Luhtein worked as a teacher at the State Applied Art School.

In the 1930s Luhtein designed packaging and advertisements for the O. Kilgas textile factory, and numerous books and journals. He designed the covers of a dozen different journals, including the most famous ones Välis-Eesti Almanak (Foreign-Estonian Almanac) (1931-1934) and Sõdur (Soldier) (19311934). On the covers of journals a functionally divided picture space, posterlike use of colour, and a clearly readable Roman font can be found (Figure 2). The nationalist theme is featured on either the ornament or the picture. Luhtein's rather elegant advertisement graphic art created in the 1930s deserves special attention. The art deco-like advertisements for Kilgas factory's silk stockings and dress material published on the last pages of the journal Teater (Theatre) (1939) are aimed at the modern woman. Font design on these advertisements by P. Luhtein is beautiful and airy, the capital letters in italics form fantasy-like arches.

Painter and graphic artist Hugo Lepik (1905-2001) successfully graduated from the State Applied Art

Figure 2. Paul Luhtein. Magazine cover. Sõdur (Soldier), no 12, 1931.

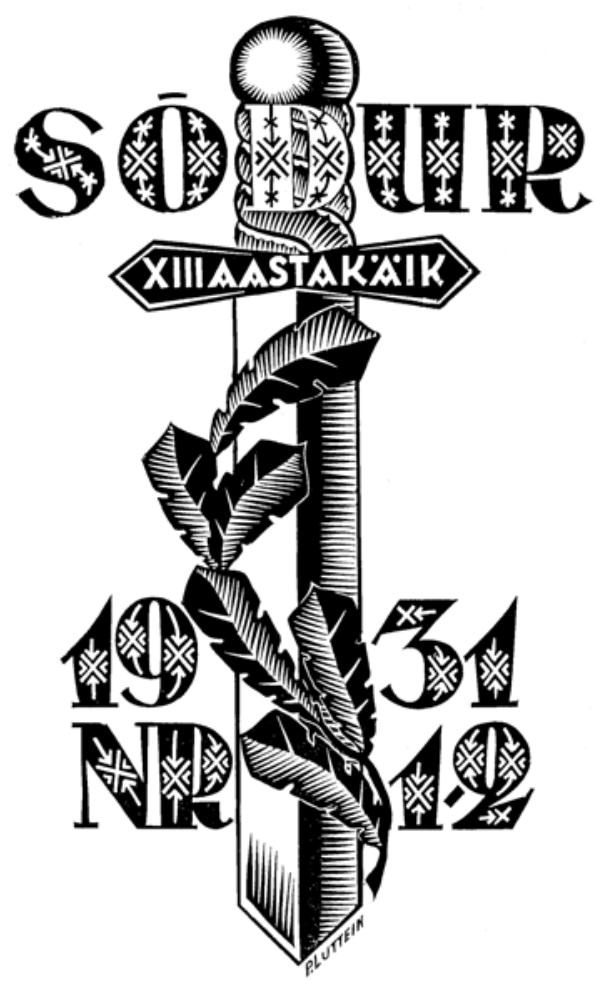


School in the fields of graphic art and lithography in 1929, and was also a student of Reindorff. In 1935, he trained at the Berlin Higher Graphic Art School. In 1929, Hugo Lepik began working as a teacher at the State Applied Art School, where he was active until 1940. From 1929 he also worked intensively in the field of book graphic design and contributed to journals, for example, cover designs and drawings for the journal Sõdur (Soldier) in 1929 and 1933, and cover designs for the journals Kaitse Kodu! (Defend Your Home!) in 1929 and Taluperenaine (Farmer's Wife) in 1939. For the journal Varamu (Treasury) (1938) he drew beautiful vignettes that were repeated from issue to issue. Hugo Lepik's style of drawing is precise and of graphics fine. The vignettes mostly depict natural motifs.

Of the students of the State Applied Art School, Werner Birkenfeldt (19031942), Eduard Salu (1906-1967), Ferdinand Liiv (1912-1948), Voldemar Tomassov (1906-1961), Axel Rossmann (1899-1974), Richard Pallas (1908-1951), Romulus Tiitus (1906-1982), Ferdinand Kask (1900-1941), Roman Haavamägi (1891-1964), Paul Liivak (1900-1942) and Eugen Vaino (1909-1969) were also active as designers of journals. Some of them adopted the externally dramatised manner characteristic of the illustrators of the Western European art deco journals. Their cover drawings depicting a carefree life were mostly stereotypical, but guaranteed a wide spread of leisure time journalism.

Werner Birkenfeldt (Verny) mostly worked for newspapers, but he also worked for journals. For a short time (1927) he studied lithography at the State Applied Art School. He was among the first to use large title drawings and photo arrangement in Estonian newspaper design. Verny became a productive drawer in the entertainment genre of the 1930s. His humorous but sweet and mellow manner was understood by the general public. Verny designed the covers of the journal Kirilind (Ladybird) (1939-1940); made vignettes, advertisement graphic art, photo arrangements, cover designs and humorous illustrations for the journal Huvitav Žurnaal (Interesting Journal); and provided cover illustrations for the journals Lood Elust (Stories from Life) (1932) and Maaomavalitsus (Rural Local Government) (1931).

For a short time (1922) another very productive designer of journals Axel Rossmann studied at the Tallinn Applied Art School. He came from the family of a printhouse worker, his father August Rossmann was master of printing at the Tallinn Applied Art School in 1923-1932 (Toom 2004: 28). Axel Rossmann designed a whole range of journal covers: Huvitav Žurnaal (Interesting Journal) (1933-1935), Kõigile (For Everyone) (1936), Käsitööleht (Handicraft Journal) (1932-1935), Kaitse Kodu! (Defend Your Home!) (1935-1939), Laste Rõóm (Children's Joy) (1931), etc. His creative work is characterised by an illustrative style with some decorativeness, which is quite similar to the cover design of 
Figure 3. Axel Rossman. Magazine cover. Huvitav Žurnaal (Interesting Journal), Spring 1935.

Finnish and Latvian women's journals, where often there is an art deco-like lady with a small dog or a bird (Figure 3$)$.

Richard Pallas graduated from the State Applied Art School in 1931 with a certificate of commendation in the field of decorative painting and spent the year 1937 in Paris as a state grant holder. He mostly worked as an advertisement artist, designing window displays, exhibitions and newspaper

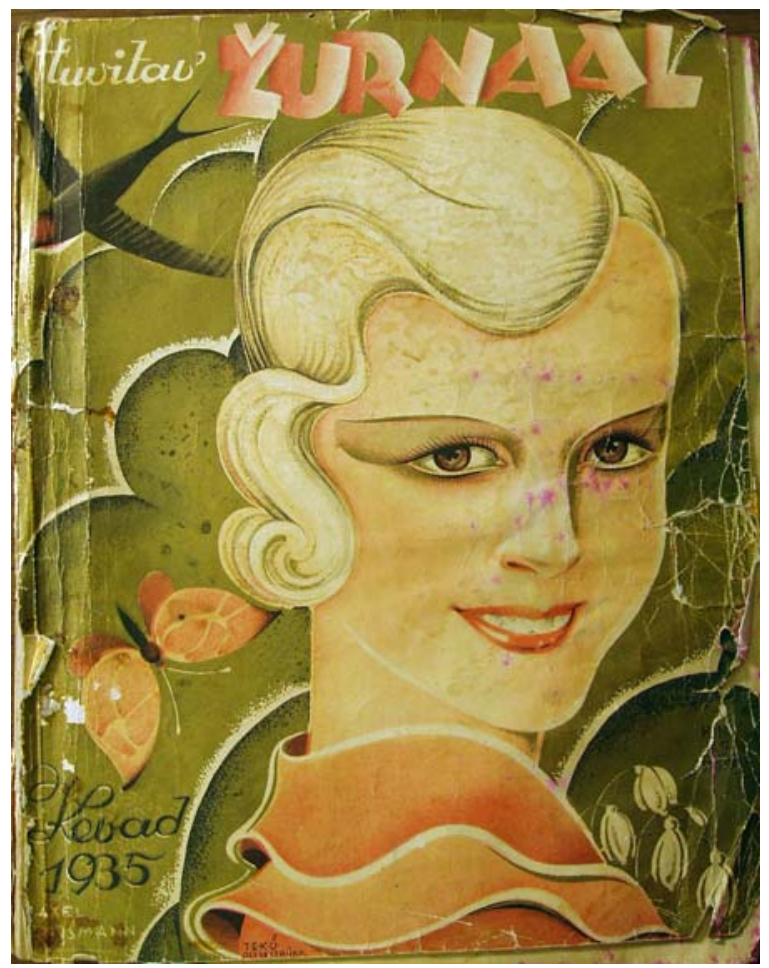
advertisements, creating banners and making cover designs for journals. His creative work is characterised as decorative and aspiring for rhythm, in the advertisements the artist is fond of motif repetitions. The cover designs of the Huvitav Žurnaal (Interesting Journal) are typical of the era, on the 1937 cover of the autumn issue we see a lady leaning on a tree, spending time in the forest. The birch trunks form a rhythmical repetition, the figure is simplified and flat.

Painter and applied artist Adamson-Eric (1902-1968), whose art education was acquired in liberal academies of Europe, briefly co-operated with Tallinn journals. Some important affairs in Estonian graphic art of journals are associated with him. Specifically, Adamson-Eric boldly interpreted nature and folk art motifs, using abstract geometric shapes alongside stylised human, bird and animal images. Issue no. 4 of the journal Varamu (Treasury) of 1939 reveals the creative work of Adamson-Eric. Adamson-Eric's characteristically individual boldly stylised vignettes with slightly naive human figures and plant motifs and initials are evident (Figure 4). In their integrity, these tiny vignettes by Adamson-Eric have much more of the so-called nationalist character that was searched for in figurative and applied art during those years, than do the items in the "belt-ornament genre" (Adamson-Eric 1932: 599) by other artists. It is true that the transfer of external attributes from folk art does not create 


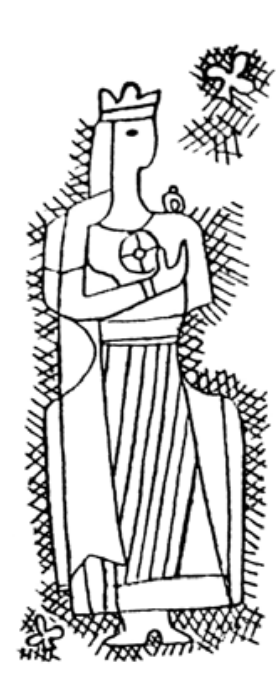

Figure 4. Adamson-Eric. Vignette. Varamu (Treasury), no 4, 1939, p. 420 .

nationalist art, but rather internal sublimation and the skill to use artistic means. If the patterns are transferred with a certain objective, artistic freedom suffers. Adamson-Eric was one of the artists who approached the nationalist theme in quite a creative manner.

Thus the Tallinn school during the 1930s laid a strong foundation for the future development of Estonian applied graphic art, guaranteeing educational sustainability. Just like in other fields, in applied graphic art it can be seen how, following the taste of the era, the Jugendstil developed into an art deco that uses geometric elements. On the other hand, the young nation state tried to stress its originality and the best way for this was considered to be the combination of the ethnic ornament with a moderately classical form (Toom 2004: 68). So it can be said that the generation of the State Applied Art School is characterised by an art deco-like stylisation, a moderate use of the national element (the ornament or other symbols) and a strong composition, based on systematic tuition. A logically built clear and readable font is also a characteristic. In the graphic design of the $1920 \mathrm{~s}$, the biggest shortcoming was the weak level of font design, as the font with other design elements did not create a united compositional whole. This shortcoming is compensated for by the creative work of graphic artists who were educated at the State Applied Art School in the 1930s. The training manner of the State Applied Art School secured an artistic style for applied graphic artists based on consideration and simplicity and supported their creative practice until the $1950 \mathrm{~s}$.

\section{THE TARTU SCHOOL}

Tartu, led by the university, has always been considered the focal point of Estonian cultural life and an intellectuality that opposes power. The opposition of power and intellect is always spoken of as an eternal and fatal regularity. In the 1930s the issue of power and intellect quite dramatically emerged as a topic for discussion (for example, Vaim... 1940). This was a time when great ideas and narratives possessed the minds of millions, when the ideas of German philosophers of the mind (above all Friedrich Nietzsche) were broadly known in Estonia as well (Ruutsoo 2002: 15-16). The intellectual elite with high self-esteem formed an opposition to the government, representing and 
mediating values that seemed important to them: the independence of the democratic intellect from power, ethics and sense of obligation, the idea of art for art's sake. The activity of the intellectual groups grew into a public confrontation during the so-called "silent era" (Karjahärm \& Sirk 2001: 217). Tartu developed into a unique centre of academic and artistic freedom. "This was a town that admitted people from all over and accepted their individual characteristics, uniting their talent into its intellectuality and making it part of its own profile," wrote the Pallas graduate Endel Kõks (1962: 91). Thus the art school Pallas, located in Tartu, was supposed to become an educational institution where artists could concentrate on the specific issues of figurative art, and avoid political performances and topical problems of art policy. The curriculum was based on firm studies of nature, professionalism was stressed and the peculiarities of every talent taken into account.

The art society Pallas, which founded the school in 1919, united artists and literati, whose intellectual background was linked to the diverse European cultural experiences. Of the founders of the art society, Konrad Mägi, Ado Vabbe, Aleksander Tassa, Friedebert Tuglas and others had spent time in France, the Netherlands, Belgium, Italy, Spain, Finland, Sweden and elsewhere in Europe during the first years of the 20th century. Such a diverse experience provided a good foundation for building up a school with a European curriculum, out of which grew the first active generation of Estonian modern art (Abel 1990: 143).

From autumn 1924 the art school Pallas worked as a higher educational institution. Pallas was a private school, maintained by the art society Pallas. The school received income from the tuition fees, subsidies from the state and local government, and donations (Nurk 1977: 58). That is why the economic situation of the school was rather tight. Only with good economic management was Pallas developed year-by-year. Despite the difficult times, a one-off scholarship for going abroad for one teacher for 60,000 Marks $^{10}$ was included in the budget. To broaden their minds the best Pallas students were also sent on trips abroad.

People who had graduated from any higher art school could be teachers at Pallas. In the 1930s graduates of Pallas were employed as tutors. Members of the teaching staff with low creative potential were excluded from the activities of the school. In Pallas it was considered good to do research work, even more so, because the unique image of the town was connected to the University of Tartu, where art students could attend lectures.

Field-related specialisation at the Higher Art School Pallas took place in studios. The choice of the field and tutor of the studio was made by the student. In the early 1930s only two painting studios operated, headed by Nikolai Triik 
and Ado Vabbe. From 1930 the graphic art studio, which for years had been one of the most difficult issues for the school, began working intensively. The graphic art studio was headed by Ado Vabbe.

As Vabbe worked in Pallas for 21 years altogether (1919-1940) and Triik for 17 years (1921-1926; 1928-1940), we can speak of the schools of these two artists. One of Vabbe's students was Hando Mugasto, who became head of the graphic art studio in the autumn of 1935. In the late spring of 1937 Mugasto passed away, and in the autumn Arkadio Laigo and Roman Vaher were employed in the studio. Vaher was skilled in intaglio techniques, and he was also able to teach calligraphy ${ }^{11}$ (Toots 1970: 13), but his manner of expression was correct and practical, which did not impress the students. On the other hand, Laigo's individual manner of figures found many followers. In the autumn of 1939 Vaher left Estonia and the work in the graphic art studio was left to Laigo alone (Nurk 1965: 35). Principally, in graphic art, Mugasto and Laigo were the grand examples of the young Pallas students, but there was also Eduard Wiiralt, who had a very individual style and worked in Pallas as a graphic art tutor in 1924-1925. In 1925, Wiiralt received a one-year scholarship for studies in Paris, where he stayed until 1939.

Sixty-four students had graduated from Pallas by 1939, 49 of them in painting (32 men, 17 women), three in graphic art ( 1 man, 2 women) and 12 in sculpture (8 men, 4 women). Altogether 79 artists had graduated from Pallas by 1940 (Karjahärm \& Sirk 2001: 209). As a comparison, 537 people graduated from the State Applied Art School between 1919 and 1939, whereas 205 from the full course of the school and 322 at the level of workshops (Karjahärm \& Sirk 2001: 209). Thus, numerically the Tallinn school was much bigger. But it was the Tartu school's creative work, with its lyrical and poetic undertone, that was able to create a magnificent international and national harmony in Estonian art. This was very important from the point of view of figurative art. In applied art the style of the Pallas graduates, compared to the Tallinn artists, was more magical, individual, there were more influences of expressionism (Eduard Wiiralt, Peet Aren) and cubist constructivism (Jaan Vahtra) in it. The weakest feature of the Tartu artists was font. Mostly they (in the context of graphic journalism art Ado Vabbe, Nikolai Triik and Peet Aren) found combinations of letters that suited the drawings in style, but that is all they were capable of in font. Hando Mugasto's complete font solutions were an exception, as was Jaan Vahtra, who on numerous covers offers heavy Grotesque font or Roman type spread across cubist and constructivist surfaces. The cultivation of such a manner also provided good results with other artists (for example, Ernst Kollom) and this has to be viewed as one of the Estonian interpretations of the bauhausstyle. 
A majority of the artists who received their art education in Pallas began working in Tartu, co-operating with journals published in Tartu. Tartu was the Estonian book capital at the time, where the most important publishing houses and the most modern graphic workshop Ilutrükk (Fine Printing) were located.

Nikolai Triik (1884-1940) was undoubtedly very experienced as an illustrator of books and journals. His works had already attracted attention in 1905 (the cover of the Noor-Eesti I album). In the 1930s, Triik was closely connected to the Tartu journals Tänapäev (The Present Time) and Olion (Was-Is). On the covers of Tänapäev we see an art deco-like composition and a solution for figures. Many covers of the issues feature famous charcoal drawing portraits of cultural people by Triik (for example, the writer Anton Hansen Tammsaare). The cover design of the first issue of Olion (1930) was made by Nikolai Triik in co-operation with his third wife and student Anna Triik-Põllusaar (19021999). This was a banner type cover using a red rectangle as a decorative element (Figure 5). The same design in a slightly simplified manner was again published in 1933, after which with every issue of the journal it was printed in a different colour.

In the 1930s, Triik's studio began to produce graduates regularly, amongst whom were the artists Ernst Kollom, Arkadio Laigo and Richard Sagrits. It is perhaps worth looking a little at their creative work.

The graphic artist Ernst Kollom (1908-1974) studied at Triik's studio in 1927-1931. Kollom was one of the most prolific graphic book artists in Estonia, mostly cultivating tonal and coloured wood engraving. In designing books and journals he aimed for an integral general impression. Kollom was very productive, a realistic wood engraving master by nature. The compositions of his works are not very varied, but still tasteful. Mugasto's influence can be seen in Kollom's manner of engraving. The manner of cutting is detailed, precise, and clean. On the cover of the 1939 issue no. 3 of Taluperenaine (The Farmer's Wife) we see a rather dry engraving by Kollom that depicts the new building of the Vanemuine theatre in Tartu. Kollom's cover designs for the journal Tänapäev are mostly photo compositions. The covers of Tänapäev no. 7 and 8 from 1937 perfectly fulfil their task, with the artistic and advertisement functions stylistically united. The artist uses a constructivist surface and Grotesque font, which in one case (no. 7/1937) is formed of photo cuts (Figure 6). The latter is difficult to read, but rather effective as a compositional element. Photo compositions as cover designs were very widespread at the time in European and U.S. journals (Figure 7) and the adoption of this type of design by Estonians was fast.

Arkadio Laigo (1901-1944) studied painting in Pallas under Nikolai Triik and Peet Aren in 1922-1927, graduating from the school's practical course, 
Figure 5. Nikolai Triik and Anna TriikPõllusaar. Magazine cover. Olion (WasIs), no 1, 1930.

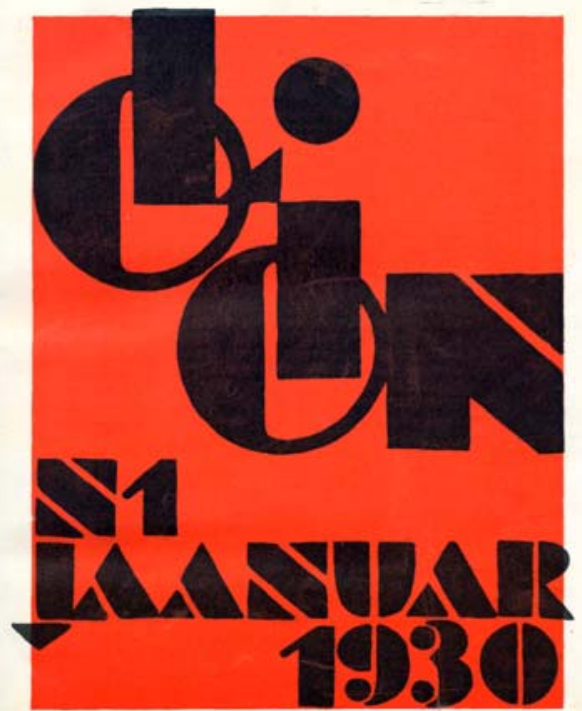

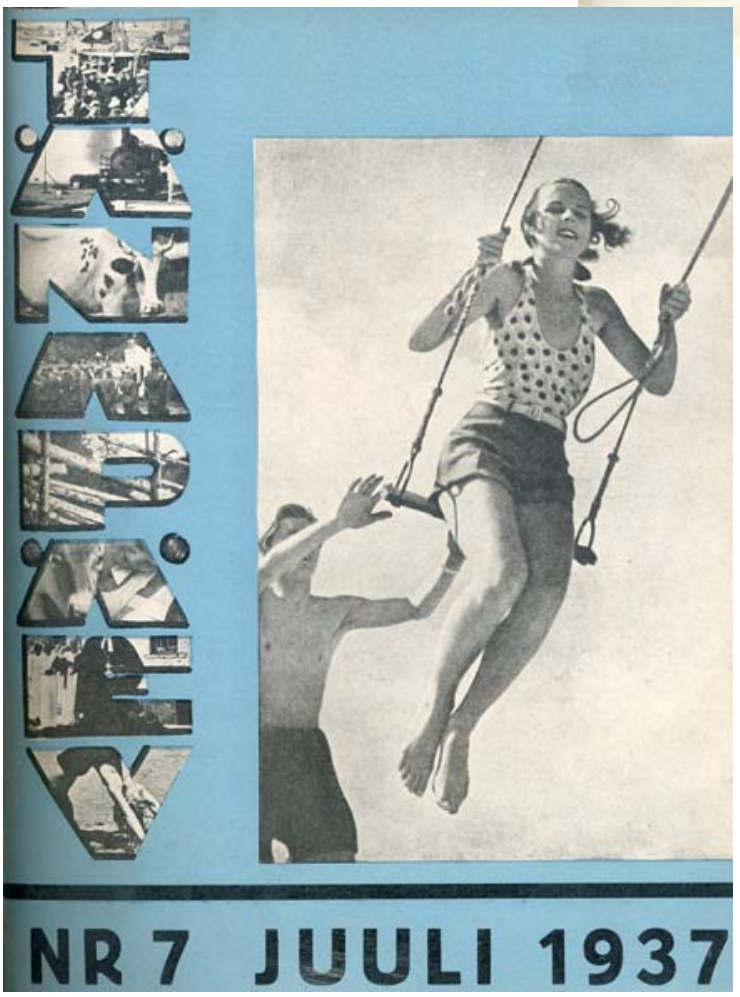

Figure 6. Ernst Kollom. Magazine cover. Tänapäev (The Present Time), no 7, 1937. 
and later was active as a graphic art tutor. Laigo's creative work is influenced by a moderate cubist manner, Lhote's example. Arkadio Laigo began cultivating graphic art consistently in 1933 . He became a notable wood engraver. His compositions are peaceful and balanced, and the form is stylised. Laigo's wood engravings were published as vignettes on the pages of the journal Tänapäev (1937-1939). His characters are heavy with massive limbs. The manner of his cutting is powerful and contrastive, without soft transitions.

Richard Sagrits (1910-1968) was an artist who introduced the picturesque manner characteristic of the Pallas school in journals. He began his art studies in 1928 at the State Applied Art School, where he studied decorative painting under Roman Nyman and graphic art under Günther Reindorff. In 1930, he transferred to Pallas and continued painting studies under Triik and graphic art studies supervised by Vabbe. Sagrits graduated from the school in 1936. He published Indian ink drawings as headers and illustrations in Tänapäev (1935), which express an emotional view of the world and a genuine sense of nature.

Another Pallas tutor to have his own school was Ado Vabbe (1892-1961). His art education was acquired in Munich, from Ažbé's art school. Between 1917 and 1940, Vabbe illustrated a total of ninety books. His contributions to journals were brief, but thus very individual and memorable. In his works we see futurist dynamics, expressionist sensitivity and a slight snobbish undertone. Vabbe was connected to the Noor-Eesti traditions, the art worlds of Beardsley and Mir Iskusstva; he personally knew Vassili Kandinsky and was influenced by the abstract impressionism of the group Der Blauer Reiter (Komissarov 1992: 7; Varblane 1994a: 183; Varblane 1994b: 1405). From all of this he synthesised his own style, which is close to art deco. His carefree and naughty Indian ink drawings with a moving rhythm were published in the monthly journal Olion. In a similar carefree, slightly lighthearted style Vabbe designed the 1930 issue no. 4 cover of Olion.

Figure 7. Travel brochure for Bermuda Air Cruises, 1938. Published by United Air Lines and Imperial Airways.

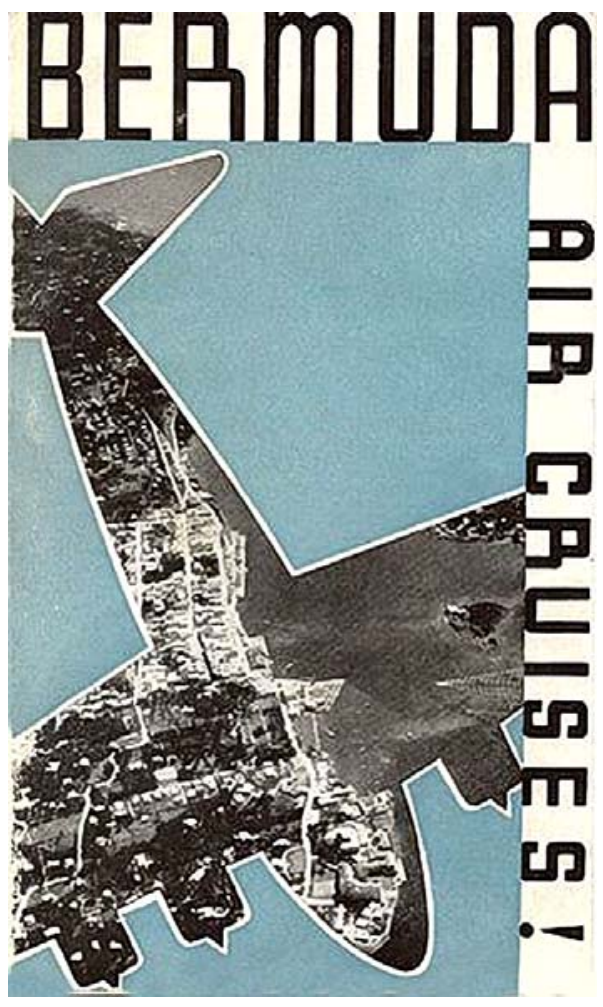


Vabbe's original interest in black-and-white art certainly influenced his students. He also transferred his desire to experiment over to his students. Elmar Kits (1913-1972), Hando Mugasto (1907-1937), Endel Kõks (1912-1983) and Ott Kangilaski (1911-1975) were students of Ado Vabbe, who were active in the field of graphic art journalism.

Elmar Kits studied at Vabbe's studio during 1935-1939, while in the field of graphic art he was Hando Mugasto's student. In the 1930s the young Elmar Kits designed student journals in Tartu. These drawings have rather interesting compositions in the lino-cut technique, but unfortunately the building up of the typeface is totally unconsidered, the forms of letters are occasional. In many other works the font remains the weakest element for Kits. The artist arrives at a mature solution in the case of the cover of the 1937 issue no. 2 of the journal Kevadik (Whitlow-grass). The font and the picture form an expressionist whole (Figure 8). In 1939, Kits published small vignettes in the lino-cut technique for Tänapäev. Here a happy and expressive manner of cutting is visible.

As a graphic artist and calligrapher Hando Mugasto (1907-1937) was the most talented of Vabbe's students. During the years 1924-1933 he studied at Pallas, and in 1935-1937 worked as a graphic art tutor there. Mugasto' sudden death on June 11, 1937 shocked the general public, leading to numerous
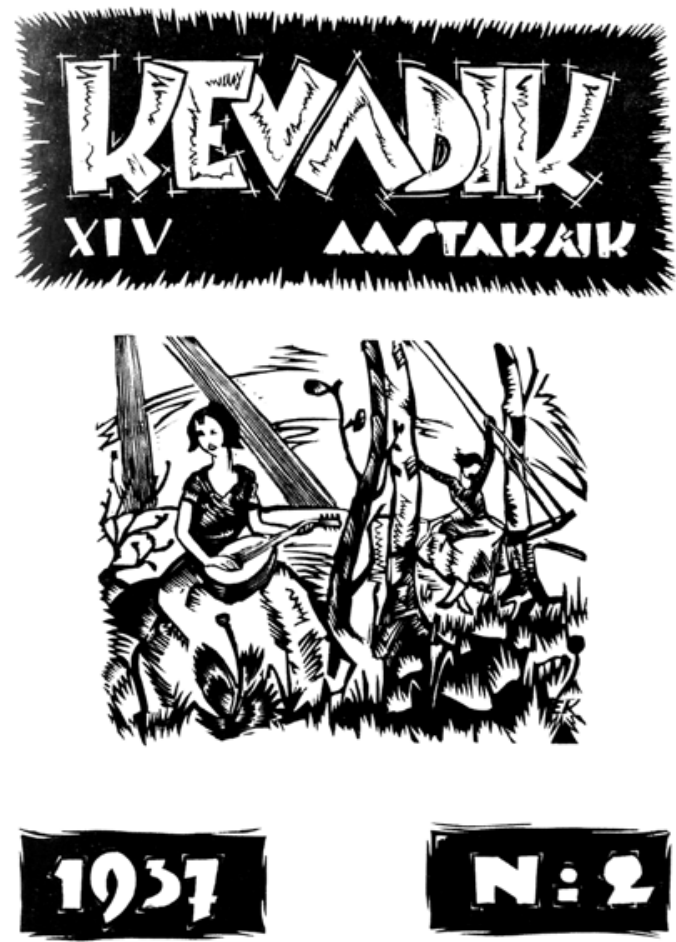
obituaries in newspapers and journals, with notes providing an overview of his creative work (Kaal 1937; Paris 1937; R. P. 1937). In Tänapäev numerous vignettes by Mugasto were published. During the last years of his life and work Mugasto had stood in an outstanding position as a graphic artist and wood engraver. Having enrolled in Pallas, Mugasto immediately felt an interest in graphic art. At the time Wiiralt was head of the graphic art workshop at Pallas. Thus the influence of Wiiralt on shaping the

Figure 8. Elmar Kits. Magazine cover Kevadik (Whitlow-grass), no 2, 1937. 
artistic style of Hando Mugasto is even more decisive than the influence of Ado Vabbe. Mugasto's creative work with a unique expression developed largely thanks to Wiiralt's far-reaching example. Mugasto looked for support, an impetus, encouragement and stimulation that was offered by the master with his example (Kaal 1937: 367). From here Mugasto's skill in composition and in following a form of speech with sense on paper began.

Being extremely prolific in graphic book art, Mugasto designed numerous vignettes and decorations for other print materials. With this he created a strong tradition for the direct introduction of original graphic creative work to broader circles. Hando Mugasto's wood engravings were published in the internal design of Tänapäev (1936-1937), Varamu (1937) and Olion (1931). Most of these are not drawings made for the journal, but works that were published earlier as illustrations of books of poetry. The journal Teater Vanemuine (Theatre Vanemuine) was published in 1935-1938 with Mugasto's cover design. This is a very artistically mature solution. The design is characterised by a constructivist surface and art deco font. In font, Mugasto was indisputably the best of the artists of the time in Tartu.

Eduard Wiiralt (1898-1954), a great model for the young Pallas students, graduated from the school in 1924 as a graphic artist and sculptor. Without getting into a thorough analysis of Wiiralt's extremely prolific creative work, which was characterised by different creative stages, it must be mentioned that there was almost no co-operation with journals. In 1935, the issue no. 11 of Taluperenaine was published with Wiiralt's cover drawing. The cover picture "Ema ja laps" ("Mother and child") (Figure 9) depicts a typical example of Wiiralt's wood engraving work. The picture has an expressionist composition - the mother and child share an eye and face, the eyes are exceptionally large compared with the features of the mouth, the hands are small and the lines are rhythmically wavy. Most likely this engraving was not made specifically for the journal.

The 1938 issue no. 3 of the journal Varamu is dedicated to Eduard Wiiralt's 40th jubilee. The journal is full of reproductions of Wiiralt's works and is decorated with his vignettes. In the vignettes the expressionist sensuousness is intertwined with a surrealist element. The figure of the bird with a human face decorating the text by Oskar Loorits "The bird - the coat of arms of Estonian indigenous culture and intellectuality" carries appalling mystery and metaphorical significance. For a moment the fantasy figures of the famous "Põrgu" ("Hell") (1930-1932) come to life again here. It is known that during his years in Paris Wiiralt tenaciously rejected the orders coming from home, which had a wearing effect on him (Levin 1998: 69). According to Jüri Hain (1984: 64) Eduard Wiiralt did not co-operate with journals at all having left Estonia and 


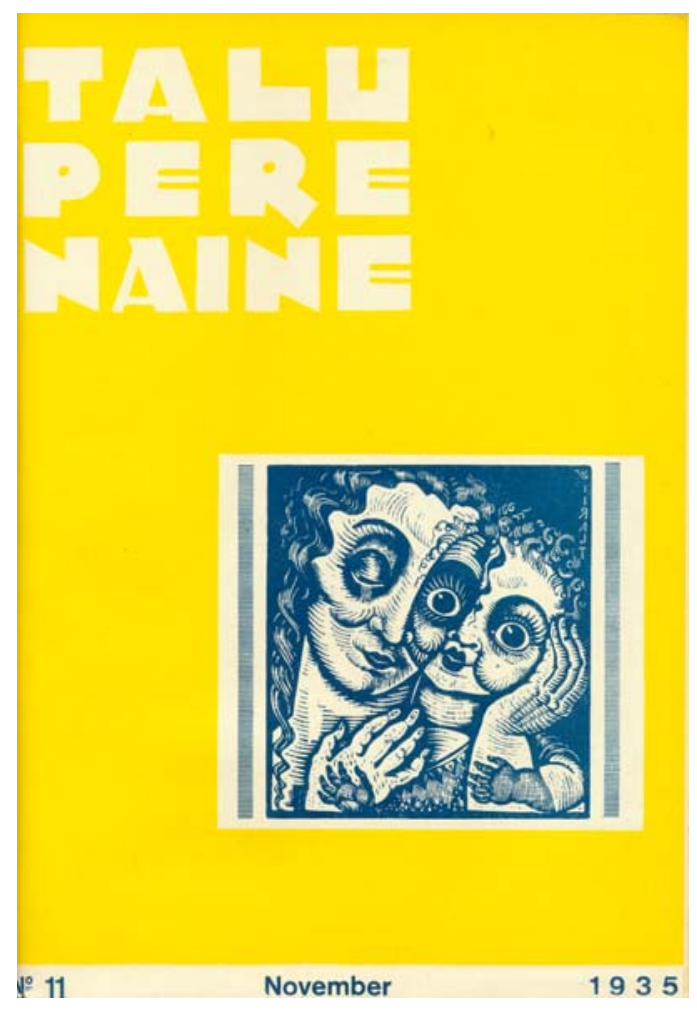

Figure 9. Eduard Wiiralt's wood engraving "Mother and Child" on the cover of Taluperenaine (The Farmer's Wife), no 11, 1935.

Varamu used the wood engravings made during the artist's Paris days. Thus it may be said that Wiiralt's contribution to Estonian graphic art in journalism and applied graphic art in general was more indirect than direct. But in 1927 Wiiralt's illustrations and wood engravings made it to the pages of the French journal of bibliophiles La Septimanie (Levin 1998: 48). The best known of these, according to Mai Levin, is the illustration "Musitseerivad inglid" ("Music-making angels"), less well known is a work with a reflective undertone "Teelahkmel" ("At the Crossroads").

Peet Aren's (1889-1970) co-operation with journals was much more extensive. He worked as a Pallas tutor in 1926-1930. Aren was educated in St. Petersburg, at the Arts Promotion Society School in 1908-1913, and later he trained in Vienna and Munich. Parallel with his painting work Peet Aren also designed banners, calendars, brochures, books, journals, ex libris, and financial graphic art. His early graphic art works expressed the national romantic and stylising manner of the Mir Iskusstva, later we witness expressionist deformation and influences from art deco. We do not encounter passion or the unity of content and form characteristic of German expressionism in Peet Aren's graphic art journalism. External, effective methods of form do not often hide special internal charges within themselves. In the early 1930s, a problematic element of his designs was the font. A more determined development in the aspirations of the artist is witnessed in the font becoming a more sustainable and clearer design component in the second half of the decade. The 1932 cover design of issue no. 4 of Kevadik (Whitlow-grass) is a mixture of expressionism and art deco, where both the ornament and figural composition are present, but the drawing has no contextual profundity. Aren's best achievements in the 
field of graphic art journalism are the cover and internal decorations to the first years of issue of the performing arts and literature monthly journal Teater (Theatre) (1934-1935). The design of the artist here forms a pleasant whole, though in some cases the relative proportions of the letters are somewhat questionable.

Karin Luts (1904-1993) studied in Pallas in 1922-1928. Her characteristically individual fine picturesqueness and the special sense of the world that dominates in her oil painting are not directly transferred to graphic art in journalism, but a firm sense of style definitely characterises her vignettes and initials. The journal Varamu has full-of-fantasy initials at the beginning of the articles drawn by Luts and her tiny vignettes are repeated from issue to issue. The artist skilfully and logically unites the belt-ornament and national motifs into ornamental initials, thus linking the nationalist tradition with a Pallaslike treatment of art. Karin Luts was otherwise connected to journals too, drawing numerous carpet patterns for the journal Kodukäsitöö (Home Handicraft) and publishing articles on Estonian and foreign modern art.

From the point of view of graphic art in journalism the creative work of Jaan Vahtra (1882-1947) is important. Jaan Vahtra, a founding member of the Eesti Kunstnikkude Rühm (Estonian Artists' Group) ${ }^{12}$ attended the Riga art school in 1912-1913 (his tutor was Vilhelms Purvitis), and studied in St Petersburg at the Arts Promotion Society School 1913-1916 and the art academy in 1918. In St Petersburg Vahtra also encountered cubo-futurism. His manner of treatment became more synthesising and the form briskly dismembering. The cubist manner persisted longest in Vahtra's creative work in book design and was expressed there most consistently (Peil 1972). In graphic art journalism Vahtra mostly created cover designs, which retained the constructivist manner. With laconic means the artist achieved an effective general impression, valuing clear and readable font. Cubism and constructivism, which are known to operate with abstract figures as opposed to the expression of feelings of expressionism, normally eliminate any kind of emotion. Only the form is important, the rational organisation of surfaces, the play of the relations of colour.

From 1936 a majority of issues of the journal Tänapäev from the Noor-Eesti publishing house were published with cover compositions by Jaan Vahtra. The simplest design was a cover divided into colour and white surfaces, in the centre of which was a photograph of nature or everyday life, with drawn Roman type letters at the top and bottom. In addition to this we also see solutions full of more fantasy (Figure 10). Vahtra also constructed several successful banner covers, and was one of the most productive journalism illustrators of the 1930s. His drawings have strong features, retaining a firm composition 


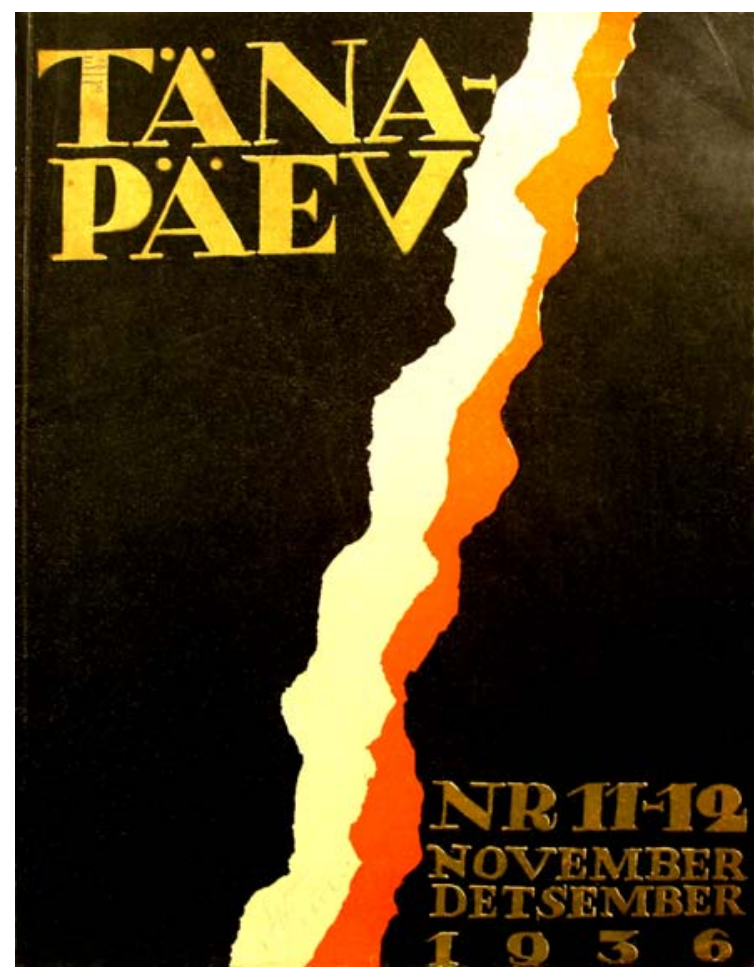

Figure 10. Jaan Vahtra. Magazine cover. Tänapäev (The Present Time), no 11-12, 1936.

and legibility of font. $\mathrm{He}$ cleansed the cover design of excessive details and overcrowding.

August Luiga (1906-?) was enrolled in Pallas in 1937, but in 1947 he graduated from Pallas' legal successor the Tartu State Art Institute. His lino-cuts were published in Olion (1935). His linos "Päikesetõus" ("Sunrise") and "Terrassil" ("On the Terrace") (Olion no. 8 and 13/1935) are the purest examples of art deco in the internal design of our journals (Figure 11). We see decorativeness and an aspiration for finesse characteristic of the style. Angular forms cross with rotundity on the drawings. The scenes are fully romantic.

The productive graphic artist Agu Peerna studied in Pallas in 1928-1932. His early works are in the manner of national romanticism, later his manner of treatment becomes more realistic, but also more expressive. Peerna mostly cultivated lino-cuts. He was fond of a more picturesque, robust cutting manner than Mugasto, Laigo or Kollom. Peerna's co-operation with journals began in the 1920s. During the next decade he published mono-engravings in Olion (19321933), and handicraft patterns and cover designs in Eesti Naine (The Estonian Woman) (1930-1935). He also made cover designs for many children's and youth journals, and co-operated closely with Tänapäev. These cover designs and illustrations in the lino-cut technique are characterised by a rough, slightly expressive manner of cutting that made the years of issue of several journals memorable and enjoyable.

From the above examples it can be said that the strength of the Tartu school was based on the co-operation between different artistic personalities. Due to the western European art experience the visual language of the artists from the Tartu school was picturesque, with slight influences of expressionism 


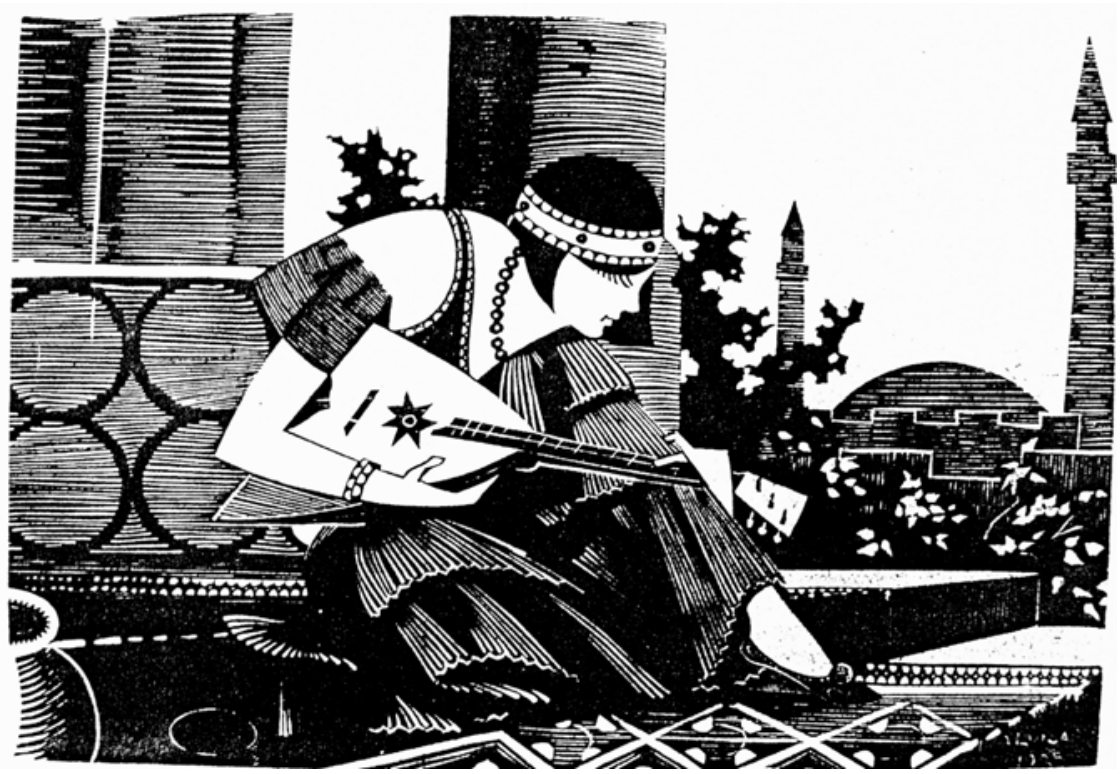

Figure 11. August Luiga's lino-cut "On the Terrace", Olion (Was-Is), no 13, 1935, p. 407.

and constructivism. Of course, a number of caricaturists also worked for Tartu and Tallinn journals, for example Gori (Vello Agori, 1894-1944), Romulus Tiitus (1906-1982) and Otto Krusten (1888-1937). But as the caricature is predominantly a journalistic genre and closely linked to the daily problems of its time, it should be discussed separately and especially in a political context.

\section{SELF-TAUGHT ARTISTS}

In addition to the two schools mentioned above, several self-taught artists were active in both Tallinn and Tartu. Either they did not have any art education, or what they had was limited to occasional or non-professional courses. Selftaught artists mostly produced advertisement graphic art for journals. Most of this advertisement graphic art published in journals is unsigned, thus the authors remain anonymous; to some extent they are disguised employees of the advertisement companies of the 1930s. Thus the following overview only touches upon one part of the self-taught applied graphic artists, those from whom enough creative material has been gathered that can be identified as theirs. ${ }^{13}$

Most of the self-taught artists created graphic book art, newspaper advertisements, packages, brands, booklets, displays for shop windows and designs 
for industry, trade and agriculture fairs. The cover designs by these artists follow Western European examples, depicting sweet scenes from everyday life with a positive undertone. Mostly these are colourful figural compositions. A characteristic example are the cover drawings of the most outstanding Tartu applied graphic artist of the time Heino Lehepuu (1907-1944) for the journal Maret (1936). According to J. Genss (1948: 72) Lehepuu designed the covers for a dozen books in the 1930s and also made interior illustrations. As a calligrapher Lehepuu was very capable (he also created the title font for Maret), but being active in the field of advertisement graphic art did not let his calligraphy talent open up entirely.

Lehepuu's co-operation with journals began in the 1920s. His manner is characterised by true-to-nature drawing, where the characters, both children and adults, have sweet, round faces. In the second half of the 1930s he made soap advertisements for A. Frederking and other companies, and designed advertisements for the Haberdashery and Lingerie Company Vennad Lepp. These were published in the journals Eesti Naine (Estonian Woman), Huvitav Žurnaal, Maret, Taluperenaine and Teater Vanemuine. Some of them are bannerlike solutions with a thought-through composition. The strong side of the soap advertisements is a good-level font. Sometimes he uses figure, which makes the design provincially sweet. However, he does not exceed the limits of good taste and creates a pleasant effect that is well composed.

Paul-Aleksander Pedersen (1906-?) was a Norwegian by nationality, who for a short time studied at the painting studio of the artist A. Kaigorodov. In 1934-1944 he worked as an advertisement artist for the big companies of Estonia of the time - the tobacco company a/s Laferme (Ltd) and the chocolate and biscuit company a/s Ginowker ja Ko (Genss 1948: 175; Raunam 1980-1990: 17). The advertisements connected to these two companies were published in the journals of the 1930s (for example, Maret 1936-1937). Pedersen's advertisements are characterised by decorative and graphic precision, we see the Roman type combined with italics that are characteristic of the artist, and close-to-nature drawing.

The artist Karl Taev (1903-1992), who worked for Tallinn journals made cover and internal designs for the journal Teater in 1936-1940 and the cover design for Looming (Creative Work) in 1939 with a series of the signs of the zodiac. He was a good drawer, who has not received sufficient attention so far. Taev's hand is characterised by fine, sensitive Indian ink drawing.

Self-taught artists generally used many human figures and monotonous smiling faces in their designs and advertisements, which was common in the journals of Western Europe, the U.S.A. and neighbouring Finland and Latvia. But often a better result was achieved when the figure was abandoned. We see 
this in August Vahtel's advertisements for the Põhjala galoshes (Teater, 1938) and Frits Johanson's tailor shop (Rahvaleht (People's Paper), 1938), and in his advertisements for the tobacco products of a/s Laferme. The latter were published in the journals Eesti Spordileht (Estonian Sports Journal) (1935), Maret (1938), Vallatu Magasin (Fun Journal) (1937), Huvitav Žurnaal (1937), Tänapäev (1939) and Teater (1939). The artist is characterised by graphically fine surfaces filled with dots or short lines and images and figures drawn with a black silhouette.

Numerous wine, coffee, cosmetic products and tobacco packages drawn full of details are featured on the advertisements in the journals Eesti Naine (1936), Teater (1936), Tänapäev (1936), Kaunis Kodu (Beautiful Home) (1937), Huvitav Žurnaal (1936-1937), Taluperenaine (1936), Sõdur (Soldier) (1934), Kodu (Home) (1936-1940) and Eesti Kool (Estonian School) (1937). The authors of these advertisement drawings were productive applied graphic artists with a similar hand, Karl Vanaveski (1909-1973) and Valter Kõrver (1904-1941). The artistic work of both artists is characterised by graphic decorativeness. The composition of Valter Kõrver is not so tightly organised and full of detail as that of Vanaveski. Kõrver uses more dark surfaces, which have a banner-like effect, and the figural solutions are often picturesque, which signifies good drawing skills. An advertisement very similar to the manner of Kõrver can be found in a journal published in Germany, Lloyd Zeitung, whose circulation in Estonia is clearly shown from the availability of single issues in second-hand bookshops in Estonia (Figures 12 and 13).

A representative of the humorous manner in Estonian graphic art journalism was the self-taught applied graphic artist Kaarel Joon (1892-1981), who was the artist for several tobacco companies. His works are characterised by a realistic drawing culture, and he made multiple pretty headers for the journal Eesti Spordileht (1933) and illustrations spiced with a countryman's humour.

\section{CONCLUSION}

As a conclusion we should recall A. H. Tammsaare, who said, "Tartu is the town of moonlight, Tallinn a town of cars," thus capturing the essence of the myths of "Tallinn's power" and "Tartu's intellect". Thus two images of towns developed in the early 20th century in Estonia (Hallas 1995: 97), the better, more conservative, more humane, and more democratic and bohemian of which was Tartu, and the more radical, commercial and immoral, but metropolitan, modern and European was Tallinn. Both towns had their own art school and 


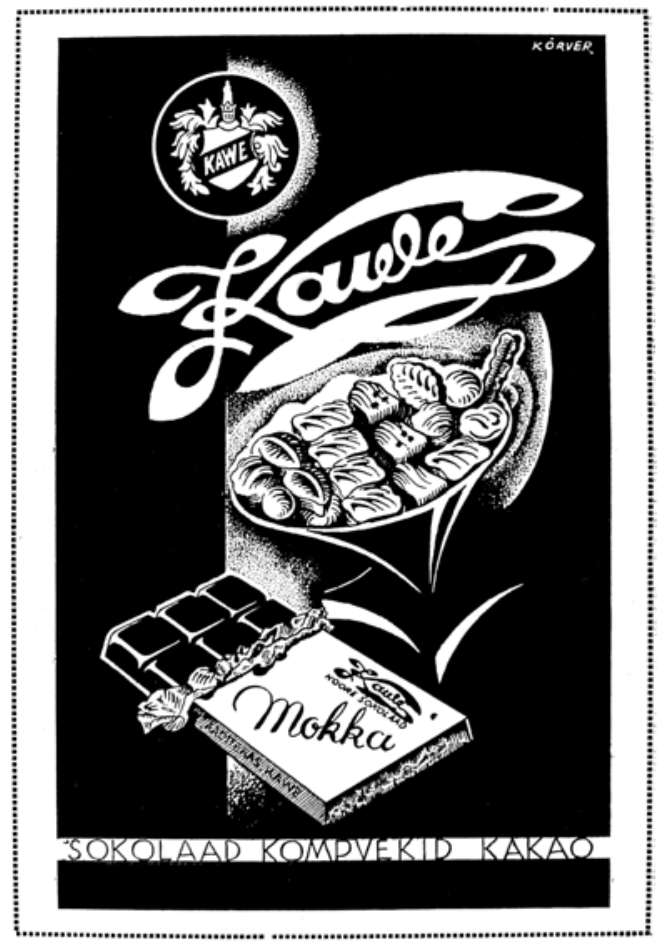

Figure 12. Valter Kõrver. Advertisement for chocolate products. Kodu (Home), no 3, 1936, back cover.

Figure 13. AMSEL. Advertisement for chocolate products. Lloyd Zeitung, no 7 , 1924, p. 3.

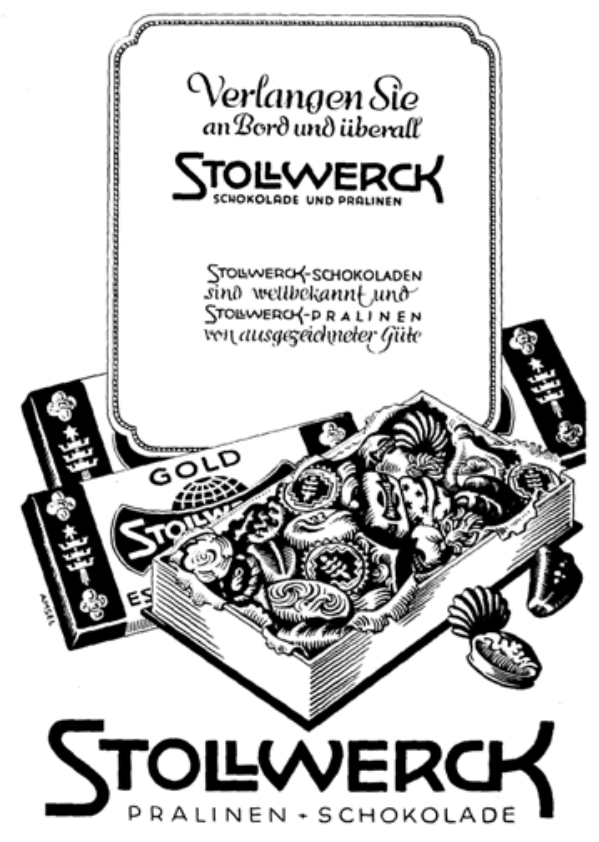


the students of both schools had their own face. The Tartu school contributed many interesting and individual artists. Nationalist propaganda is less evident in their works, and the artistic creation of artists was bigger, but due to the lack of systematic tuition the font was often unprofessional. The models for the Tallinn (State) Applied Art School curricula were the curricula of the St Petersburg Stieglitz Applied Art School with its industrial profile, which were characterised by teaching of font and ornament. The ethnographic element was widely used.

A common feature for both schools was art deco with its refined decorativeness and salon-like appearance, the ambitions of representativeness and luxury characteristic of the style, with the tamed and adapted elements of the avantgarde movements. The propaganda of nationalism that went into full swing during the so-called "silent era" was added to this, the search for an identifiable Estonian style, which played an important role in pictures and words in the journals of the 1930s, although more in the context of Tallinn than Tartu. Tartu, again, gave an impetus to the rise of individuality. Thus the look of our graphic art journalism was quite varied. The two active schools complemented one another rather successfully. The differences mostly occurred on account of different individual personalities, and self-taught artists also had their say in this.

\section{Comments}

1 RaKÜ - Association of Applied Artists, an organisation of Estonian applied artists that operated in 1932-1940. It united applied artists, promoted their creative work and defended their professional interests. Eight exhibitions were organised.

${ }^{2}$ Guido Mamberg (1895-1954) studied in Copenhagen, at the Royal Danish Academy of Fine Arts, then later improved his skills in Germany, Sweden Austria, Czechoslovakia and the UK; he was a member of several applied graphic art associations. His works have been presented in the journals Gebrauchsgraphik, Advertising Display and Dansk Reklame.

3 Edmond Arnold Blumenfeldt (1903-1946) was a painter, designer and set designer. In 1920-1922 he studied in Berlin, at the A. Reimann school of applied art and set design, improved his skills at the private academies in the art deco capital Paris in 1923-1924, while at the same time working as a set designer and advertisements artist.

${ }^{4}$ In 1845, Stieglitz bought the Narva Kalevi Manufaktuur (Baize Factory) and in 1851 founded the Narva Linaketramise Manufaktuur (Flax Spinning Factory).

5 Voldemar Päts was the brother of the pre-war president of the Republic of Estonia, Konstantin Päts. 
${ }^{6}$ Whereas at the end of the 19th and at the beginning of the 20th century the illustration was not supposed to be novel, in the 1920s and 1930s the attitude to foreign borrowings changed. The generation of the Applied Art School were the first staff trained in Estonia and when they commenced work, foreign borrowing decreased considerably.

${ }^{7}$ Noor-Eesti - a movement of literature and general culture in Estonia at the beginning of the 20 th century.

8 The flower ornament of the embroidery of North Estonia that G. Reindorff uses in his works actually comes from 17th-century Baroque art. The exuberant naturalist decoration that flourished in Baroque art - flowers, fruits, and birds - spread not only in embroidery, but also in knitwear, silver items, murals and even stone sculpture. Flower ornament containing exotic and fantastic flowers and fruits appears in Estonian folk art as different variations of the Baroque, Rococo and Classicist styles. Just like in urban culture, it has gone through all 17th- and 18th-century development stages of the flower ornament in folk art (Üprus 1969: 22). We see it on bonnets and sleeves.

9 The general name art deco signifies a clearly separate style in decorative art, which emerged in Europe directly before the First World War and dominated in fashion until the end of the 1930s. Art deco grew out of many different movements of art and design of the early 20th century, among which the Jugendstil, the Vienna Secession, German design of Werkbunds, Russian constructivism and Dutch De Stijl are worthy of mention (Sternau 1997: 10).

${ }^{10}$ In 1921, the scholarship was awarded to Konrad Mägi. The next summer Ado Vabbe travelled to Germany and Greece to learn about decorative painting. In 1923, Anton Starkopf went to Germany with grant-holding students. In 1924, a one-time subsidy was given to Ado Vabbe to learn about decorative painting in Paris (Nurk 1977: 43).

${ }^{11}$ Applied graphic art or font were not directly taught at Pallas, from which stems the uncertainty of the Pallas artists in calligraphy.

${ }^{12}$ Eesti Kunstnikkude Rühm (EKR) (Estonian Artists' Group) was an Estonian artistic society founded in 1923, whose members were united by an interest in cubism and constructivism.

${ }^{13}$ The creative work identified by the author in the history of Estonian applied graphic art begins with the early 20 th century. Still, it is difficult to identify from the overall production of applied graphic art. A basis for the development and spread of applied graphic art is the development of the country's economy and trade, thus the large volume of work determined the in-flow of the less skilled and perhaps due to the suggestions of industrialists the copying of foreign examples, especially in packages and advertisements for tobacco products. 


\section{References}

\section{Archive materials and manuscripts}

Genss, J. 1948. Eesti Kunsti materjale. III osa. Kunstnike leksikon. [Materials of Estonian Art. Vol. 3. Artists.] Tallinn: Rahvusraamatukogu.

Raunam, O. 1980-1990. Eesti tarbegraafika VI. Eesti tarbegraafikud.[Estonian applied art, vol. 6. Estonian applied artists.] Archives of the Estonian Literary Museum, EKM f 30 n $1 \mathrm{~s} 2$.

Riigi Kunsttööstuskooli juures asuva Trükitööstuskooli 1938/1939 õppeaasta tunnikavad, õppejõudude nimekirjad ja kirjavahetus. [Curricula, list of faculty members, and correspondence of the State Print School at the State School of Applied Art in 1938-1939.] Estonian National Archives f 1108 c 6 p 843.

\section{Publications}

Abel, T. 1995. "Pallase" koolkonnast 1930. aastate kunstiprotsesside foonil (Sissejuhatus koolkonna loomingu käsitlusse).[On the Pallas School in the context of art processes in the 1930s. Introduction into the school's creative production.] Kunstiteaduslikke uurimusi. 8. Tallinn: Teaduste Akadeemia Kirjastus, pp. 143-166.

Adamson-Eric. 1932. Hispaania kiri eestilikkusest. [A letter from Spain about Estonianness.] Looming, 5, pp. 595-599.

Bernstein, B. 1979. Inimesekontseptsioon eesti kunstis. [Concept of man in Estonian art.] In: Bernstein, B. Ringi sees ja ringist väljas. [In and outside of the circle]. Tallinn, pp. 128-140.

Borsi, F. 1987. The Monumental Era. European architecture and Design. 1929-1939. New York.

Hain, J. 1984. Eduard Viiralt rakendusgraafikuna.[Eduard Viiralt as an applied artist.] Kunst: Kujutava ja tarbekunsti almanahh [Almanac of fine and applied arts], 65(3), pp. 60-65.

Hain, J. 1992. Mees, kes tahtis tulla Tartu. [The man who wanted to visit Tartu] Looming, 1, pp. 139-141.

Hallas, K. 1995. Eestlane ja suurlinn. [Estonian and the city.] Kunstiteaduslikke uurimusi, 8. Tallinn: Teaduste Akadeemia Kirjastus, pp. 90-121.

Kaal, A. 1937. Hando Mugasto inimesena. [Hando Mugasto in person.] Tänapäev, 12, pp. 367-368.

Kalm, M. 1994. Arhitekt Alar Kotli. [Architect Alar Kotli.] Tallinn: Kunst.

Karjahärm, T \& Sirk, V. 2001. Vaim ja võim. Eesti haritlaskond 1917-1940. [Intellect and power. Estonian intelligentsia in 1917-1940.] Tallinn: Argo.

Kirme, K. 1975. Tallinna Kunsttööstuskool. [Tallinn School of Applied Art.] Kunst: Kujutava ja tarbekunsti almanahh, 47 (1), pp. 14-17.

Kirme, K. 1994. Tallinna Kunsttööstuskool kui kunstihariduse andja. [Tallinn School of Applied Art as educator in fine arts.] Kultuurileht, 11. nov. 
Kodres, K. 2001. Ilus maja, kaunis ruum. Kujundusstiile Vana-Egiptusest tänapäevani. [Beautiful house, nice room. Interior design from Ancient Egypt till today.] Tallinn: Prisma Prindi Kirjastus.

Komissarov, E. 1992. Vabbe - helesinine ratsanik. [Vabbe: the azure horse-rider.] Kunst: Art in Estonia, 3, pp. 7-9.

Kõks, E. 1962. Kilde Tartu profiilist. [Fragments of Tartu.] Tulimuld, 2, pp. 91105.

Levin, M. 1998. Eduard Wiiralt 1898-1954. Tallinn: EKM.

Levin, M. \& Sirkel, E. 1989. Günther Reindorff. 100 a. sünnist. Näituse kataloog. The centenary of Günther Reindorff. Exhibition catalogue.] Tallinn: EKM.

Loodus, R. 1980. Paul Luhtein ja tema looming. [Paul Luhtein and his creation.] Tallinn: Eesti Raamat.

Nurk, T. 1965. Kõrgema kunstikooli “Pallas” osa eesti graafika arendamisel. [Higher art school "Pallas" in developing Estonian graphic art.] Kunst: Kujutava ja tarbekunsti almanahh, 2, pp. 31-36.

Nurk, T. 1977. Kõrgem kunstikool "Pallas" 1919-1940. [Higher art school Pallas 1919-1940.] Tallinn: Kunst.

Paris, R. 1937. Hando Mugasto. Varamu, 1, pp. 98-101.

R. P. = Paris, R. 1937. Mõtteid Hando Mugasto loomingust. [Contemplating about the creation of Hando Mugasto.] Tänapäev, 7, pp. 219-220.

Peil, M. 1972. Lõik eesti kunstist. [A segment of Estonian art.] Sirp ja Vasar, 25(1489), 23. juuni.

Ruutsoo, R. 2002. Võimu vaimust ja vaimu võimust. [On the intellect of power and the power of intellect.] Riigikogu Toimetised (RiTo), 5, pp. 13-23. Tallinn: Riigikogu Kantselei.

Sternau, S. A. 1997. Art Deco. Flights of Artistic Fancy. New York: Smithmark Publishers.

Toom, M. 2004. Riigi Kunsttööstuskool 1914-1940. [State School of Applied Art 1914-1940.] Tallinn: Eesti Kunstiakadeemia Toimetised 14.

Toots, V. 1970. Kirja osa eesti raamatugraafikas. [The role of text in Estonian cover design.] Kunst: Kujutava ja tarbekunsti almanahh, 37 (2), pp. 10-21.

Vaim... = Vaim ja võim 1940. Album Eesti Üliõpilaste Seltsi "Veljesto" 20-ks aastapäevaks. [Intellect and power. Album for the 20th enniversary of Estonian Student Fraternity Veljesto.] Tartu: EÜS Veljesto kirjastus.

Varblane, R. 1994a. Ado Vabbe ja moodne kunst. [Ado Vabbe and modern art.] Kunstiteaduslikke uurimusi, 7. Tallinn: Kunst, pp. 180-198.

Varblane, R. 1994b. Avangardism ja traditsionaalsus Ado Vabbe loomingus [Avant garde and traditionality in Ado Vabbe's creation.] Looming, 10, pp. 1403-1418.

Üprus, H. 1969. Eesti Rahvakunst kunstiajaloo aspektist. [Estonian folk art in the context o art history.] Etnograafiamuuseumi aastaraamat XXIV, Tallinn, pp. 7-36. 